\title{
GMR
}

\section{Production of hGFAP-DsRed transgenic Guangxi Bama mini-pigs via somatic cell nuclear transfer}

\author{
L.L. Hu, Y.Q. Lu, H.Y. Xu, X.G. Yang, S.S. Lu and K.H. Lu \\ State Key Laboratory for Conservation and Utilization of Subtropical Agro-Bioresources, \\ and College of Animal Science and Technology, \\ Guangxi High Education Laboratory for Animal Reproduction and Biotechnology, \\ Guangxi University, Nanning, China \\ Corresponding authors: K.H. Lu / S.S. Lu \\ E-mail: khlu@gxu.edu.cn / shengshenglu@sina.com
}

Genet. Mol. Res. 14 (4): 16285-16296 (2015)

Received June 12, 2015

Accepted August 26, 2015

Published December 8, 2015

DOI http://dx.doi.org/10.4238/2015.December.8.19

\begin{abstract}
The mini-pig is a useful animal model for human biomedical research due to its physiological similarity to humans and the ease of handling. In order to optimize the efficiency of production of transgenic Bama mini-pigs through somatic cell nuclear transfer (SCNT), we examined the effects of contact inhibition, roscovitine treatment, and serum starvation on the cell cycle synchronization and transgenic cloned embryo development in vivo and in vitro after nuclear transfer. The analysis showed that the rates of G0/G1 stage cells in the contact inhibition (92.11\%) and roscovitine treatment groups $(89.59 \%)$ were significantly higher than in serum starvation group $(80.82 \%)$. A higher rate of apoptosis was seen in the serum starvation group (14.13\%) compared to the contact inhibition and roscovitine treatment groups (6.71 and $2.46 \%$ respectively, $\mathrm{P}<0.05$ ). There was a significant decrease in blastocyst yield in the serum starvation group $(14.19 \%)$ compared to the roscovitine treatment and contact inhibition groups (21.31 and $20.32 \%$ respectively, $P<0.05$ ). A total of 1070 transgenic cloned embryos derived from the three treatment groups were
\end{abstract}


transferred to surrogate sows; one pregnancy was established and three embryos from the roscovitine treatment group successfully completed gestation. These results indicate that the roscovitine treatment was more effective at synchronizing transgenic kidney cells in Bama mini-pigs and allowed reconstructed embryos to develop to full term.

Key words: Cell-cycle synchronization; Bama mini-pig; Kidney fibroblasts; Transgenic cloned embryos; Somatic cell nuclear

\section{INTRODUCTION}

The Bama mini-pig is a miniature porcine species from the Guangxi province of China. Due to the many physiological, anatomical, and genetic similarities between pigs and humans, there is considerable interest in their use in biomedical research. Miniature pigs such as Bama minipigs are of particular interest because their small size is an advantage for studies in biomedicine, human metabolism, pharmacology, and vascular imaging (Li et al., 2006; Mei et al., 2010; Liu et al., 2008, 2014).

The combination of somatic cell nuclear transfer (SCNT) and transgenesis methodologies has proven to be a viable approach to the production of transgenic animals. However, the efficiency of producing transgenic pigs using SCNT technology is still very low (Lai et al., 2002; Fujimura et al., 2008; Knosalla et al., 2009; Jeong et al., 2013). An important factor that affects the developmental potential of cloned offspring is the cell cycle stage of the donor nucleus. If the cell-cycle stage of the donor nucleus and the recipient oocyte cytoplasm is coordinated, then the cloned embryo can maintain normal ploidy and acquire normal development potential (Campbell et al., 1996). Wilmut and colleagues (2007) reported that using donor cells in the G0 phase for nuclear transfer improved the rate of development of cloned embryos. Several animal species have now been cloned using the G0/G1 stage of the cell cycle as the donor nucleus for SCNT, for example, in mice (Wakayama et al., 1998), cattle (Wells et al., 1999), and pigs (Onishi et al., 2000; Polejaeva et al., 2000).

Donor cells can be induced to synchronize at the G0 or G1 stage by serum starvation (Cho et al., 2002) or contact inhibition (Boquest et al., 1999; Lee et al., 2005; McElroy et al., 2008). Chemical inhibitors as butyrolactone I (Kitagawa et al., 1994), aphidicolin (Pedrali-Noy et al., 1980), demicolcine (Liu et al., 2004) and DMSO (Hashem et al., 2007; Koo et al., 2009b) can effectively synchronize cells at G0/1 and have been successfully used in SCNT. Recently, a potent inhibitor of the cyclin-dependent kinase 2 roscovitine was shown to be effective at G0/G1 stage synchronization in cells of various animal species, including wild cat (Gomez et al., 2003), cattle (Bordignon and Smith, 2006; Sun et al., 2008), dog (Koo et al., 2009a), pig (Park et al., 2010) and water buffalo (Selokar et al., 2012). Roscovitine-treated cells could be effectively reprogrammed in SCNT and resulted in improvement of the developmental potential of cloned embryos (Gibbons et al., 2002).

Inducing cell cycle synchronization can increase the rate of apoptosis in cells (Lindenboim et al., 1995; Li et al., 2014); however, it has been reported that treating donor cells with an apoptosis inhibitor improves the developmental potential of cloned embryos (Park et al., 2004). Previous research focused on cell cycle synchronization using non-transgenic cells. As the introduction of an exogenous gene might affect the cell genotype and phenotype, and possibly cause a different response to the synchronization treatment, it is important to investigate the effect of genetic 
manipulation of donor cells. This study was initiated to evaluate the effect of cell cycle synchronization on transgenic kidney fibroblast cells from the Guangxi Bama mini-pig; three synchronization methods were examined, namely, serum starvation, roscovitine treatment, and contact inhibition. The results of this study should aid the optimization of protocols for producing transgenic pigs.

\section{MATERIAL AND METHODS}

Unless otherwise stated, all Chemicals were purchased from Sigma Chemical Co. (St. Louis, MO, USA).

\section{Establishment and culture of donor fibroblasts}

Kidney fibroblasts were isolated from a newborn Guangxi Bama mini-pig. Kidney tissue was washed twice with $75 \%$ alcohol, and 3 times with DPBS (Dulbecco's Phosphate-Buffered Saline; Invitrogen, Carlsbad, CA, USA), and then minced using scissors. The minced tissue was washed 3 times with DPBS, and once with DMEM, then placed on plastic Petri dishes. After 6 h, 3 $\mathrm{mL}$ DMEM medium supplemented with $10 \%$ fetal bovine serum (FBS, hyclone), $1 \%(\mathrm{v} / \mathrm{v}$ ) minimal essential medium (MEM), nonessential amino acid solution (Invitrogen), $25 \mathrm{mM} \mathrm{NaHCO}, 1 \mathrm{mM}$ sodium pyruvate, and $0.066 \mathrm{~g} / \mathrm{L}$ penicillin and $0.1 \mathrm{~g} / \mathrm{L}$ streptomycin was added and the tissues were cultured at $37^{\circ} \mathrm{C}$ in a humidified $5 \% \mathrm{CO}_{2}$ atmosphere. The culture medium was changed every two days. The cells grew to $90 \%$ confluence after 6-10 days incubation; tissue clumps were then removed and the cells were washed 3 times with DPBS. The cells were dissociated by incubating in $0.25 \%$ trypsin $/ 0.02 \%$ EDTA for $5 \mathrm{~min}$ at $37^{\circ} \mathrm{C}$, transferred to a centrifuge tube and centrifuged at $1500 \mathrm{rpm}$ for $5 \mathrm{~min}$. The cell pellet was resuspended in $2 \mathrm{~mL}$ culture medium and either seeded into $35 \mathrm{~mm}$ plastic culture dishes for further passage or frozen and stored in liquid nitrogen. The crypreservation medium had 70\% (v/v) DMEM, 20\% (v/v) FBS, and 10\% (v/v) DMSO. Frozen kidney fibroblasts were thawed at $37^{\circ} \mathrm{C}$, and the cell suspension was transferred to $15 \mathrm{~mL}$ plastic centrifuge tubes, centrifuged at $1500 \mathrm{rpm}$ for $5 \mathrm{~min}$, and the supernatant removed and cells seeded into DMEM supplemented with $10 \%$ FBS for subculture.

\section{Transfection of kidney fibroblast cells with a hGFAP-DsRed plasmid}

Bama mini-pig kidney fibroblast cells were passaged three times in culture before use in transfection. The cells were seeded into a 24 -well culture plate at 8-10 $\times 10^{4}$ cells/well density and grown to $70-80 \%$ confluence. The transfection mixture was prepared by adding $1.25 \mu \mathrm{L}$ Lipofectamine 2000 and $0.7 \mu \mathrm{g}$ hGFAP-DsRed plasmid to $100 \mu \mathrm{L}$ DMEM that was free of serum and antibiotics. The mixture was incubated for $30 \mathrm{~min}$ at room temperature and $100 \mu \mathrm{L}$ was added to each well. After $6 \mathrm{~h}$, the transfection mixture was removed and the cells were cultured for 48 $\mathrm{h}$ with fresh DMEM. The cells were then subjected to selection in DMEM containing $300 \mu \mathrm{g} / \mathrm{mL}$ zeocin for 2 weeks. The surviving colonies were isolated and seeded into 96-well plates and stable cell lines were either subcultured or cryopreserved.

\section{Cell treatment}

hGFAP-DsRed transgenic cells were divided into three groups for synchronization treatment. Group 1: cells were cultured in DMEM supplemented with $10 \%$ FBS for 5 days until 
$90 \%$ of the cells were confluent. Group 2: cells were cultured in DMEM supplemented with $10 \%$ FBS and $15 \mu \mathrm{M}$ roscovitine (Sigma) for $24 \mathrm{~h}$. Group 3: cells were cultured in DMEM supplemented with $0.5 \%$ FBS for 5 days.

\section{Cell cycle analysis by flow cytometry}

Cells from the three groups were harvested using $0.25 \%$ trypsin $/ 0.02 \%$ EDTA, suspended in DPBS, and centrifuged at $1500 \mathrm{rpm}$ for $5 \mathrm{~min}$. The supernatant was then removed, and the cells gently resuspended in $0.25 \mathrm{ml}$ DPBS containing $5 \mu \mathrm{L} 10 \mathrm{mg} / \mathrm{mL}$ RNase and $0.1 \%(\mathrm{v} / \mathrm{v})$ Triton X-100 for $20 \mathrm{~min}$ at $37^{\circ} \mathrm{C}$ for $1 \mathrm{~h}$. They were then stained by adding $10 \mathrm{~mL} 1 \mathrm{mg} / \mathrm{mL}$ propidium iodide for 5 min and analyzed by flow cytometry (Becton Dickinson. USA).

\section{Flow cytometric analysis of apoptosis}

The rate of apoptosis in the three groups was determined using the Annexin V-FITC Apoptosis Detection Kit (APOAF, Sigma) following the manufacturer instructions. Cells were harvested using $0.25 \%$ trypsin/0.02\% EDTA, suspended in DPBS, and centrifuged at $1500 \mathrm{rpm}$ for $5 \mathrm{~min}$. The supernatant was decanted and the cells were gently resuspended in binding buffer at 1 $x 10^{6}$ cell $/ \mathrm{mL}$ concentration. Annexin V FITC conjugate and propidium iodide solutions were added to each cell suspension and the cells were incubated at room temperature for $10 \mathrm{~min}$. Stained cells were analyzed by flow cytometry using $488 \mathrm{~nm}$ excitation and 530 and $>575 \mathrm{~nm}$ emission. A total 10,000 cells was recorded per sample. Live cells showed no fluorescence, early apoptotic cells stained with FITC, and late apoptotic cells stained with both propidium iodide and FITC.

\section{Real-time RT PCR}

Total RNAs from cells of the three groups were extracted as described previously (Park et al., 2010) using the 7300 real-time PCR system (Applied Biosystems, Carlsbad, CA, USA). The primers for gene amplification are listed in Table 1. Amplification was performed using SYBR Premix Ex Taq (Takara, Japan), and all PCR products were analyzed using the 7300 system SDS software version 1.3 (Applied Biosystems).

\begin{tabular}{|c|c|c|}
\hline Gene & Primer sequence $\left(5^{\prime}-3^{\prime}\right)$ & GenBank accession No. \\
\hline \multirow[t]{2}{*}{ BAX } & F: TAAACTGGTGCTCAAGGCCC & BAX XM_003355974 \\
\hline & R: AAAGTAGGAGAGGAGGCCGT & \\
\hline \multirow[t]{2}{*}{ BCL-2 } & F: CCAGGGACAGCGTATCAGAG & BCL-2 AB116145 \\
\hline & R: CAAGTTGCGATCCGACTCAC & \\
\hline
\end{tabular}

\section{Ovary recovery and in vitro oocyte maturation}

The procedures for ovary collection and in vitro maturation of oocytes were as described previously (Liu et al., 2014) Follicular fluid and cumulus-oocyte complexes (COCs) were aspirated from follicles 3-6 mm in diameter Oocytes with uniform cytoplasm and at least three layers of intact cumulus cells were selected and washed three times in TL-HEPES containing $0.1 \% \mathrm{w} / \mathrm{v}$ polyvinyl 
alcohol (PVA), and washed twice with maturation medium TCM199 (Invitrogen). Thirty COCs were cultured in each $200 \mu \mathrm{L} \mathrm{TCM}-199$ medium at $39^{\circ} \mathrm{C}$ and $5 \% \mathrm{CO}_{2}$ in air with $100 \%$ humidity. The maturation medium used in this study was TCM-199 supplemented with $0.57 \mathrm{mM}$ cysteine, $10 \mathrm{ng} /$ $\mathrm{mL}$ epidermal growth factor, $10 \mathrm{IU} / \mathrm{mL} \mathrm{FSH}, 10 \mathrm{IU} / \mathrm{mL} \mathrm{LH}$ and $10 \%(\mathrm{v} / \mathrm{v})$ porcine follicular fluid. The COCS were cultured for $20-22 \mathrm{~h}$, and then transferred to the maturation medium without hormone for another 22-24 h.

\section{Nuclear transfer}

SCNT was performed as described previously (Liu et al., 2014) Briefly, after maturation culture for 42-46 h, oocytes with a first polar body and a uniform cytoplasm were selected for nuclear transfer. The first polar body and the metaphase II spindle plate with a small amount of surrounding cytoplasm were removed and a single donor cell with a smooth surface was transferred into the perivitelline space through the same hole. The manipulated oocytes were washed three times and transferred to PZM-3 supplemented with $0.4 \% \mathrm{BSA}$ and cultured at $39^{\circ} \mathrm{C}$ in humidified air containing $5 \% \mathrm{CO}_{2}$ for $30 \mathrm{~min}$.

\section{Electrical activation/fusion}

Activation/fusion of reconstructed embryos was as described previously (Liu et al., 2010) with slight modifications. In brief, the couplets were cultured for $30 \mathrm{~min}$ in PZM-3, then washed 3 times with activation/fusion medium ( $0.25 \mathrm{M}$ mannitol supplemented with $0.01 \%$ polyvinyl alcohol, $0.5 \mathrm{mM}$ HEPES, $0.1 \mathrm{mM} \mathrm{CaCl} \cdot 2 \mathrm{H}_{2} \mathrm{O}$ and $0.1 \mathrm{mM} \mathrm{MgCl} \cdot 6 \mathrm{H}_{2} \mathrm{O}$ ), and equilibrated in fusion medium for $5 \mathrm{~min}$. Electrofusion was performed with oocyte-cell couplets sandwiched between a pair of handmade platinum electrodes (150 $\mu \mathrm{m}$ diameter) connected to a micromanipulator. One DC pulse (1.5 $\mathrm{kv} / \mathrm{cm}$ ) for $30 \mu \mathrm{s}$ was provided by a BTX Electro-cell Manipulator 2001 (BTX, San Diego, CA, USA).

\section{In vitro culture of reconstructed embryos}

After activation, reconstructed embryos were washed 5 times and incubated for 30 min in PZM-3 containing $0.4 \%$ BSA and evaluated for fusion under a stereomicroscope. Fused embryos were first cultured for $3 \mathrm{~h}$ in PZM-3 medium supplemented with $7.5 \mu \mathrm{g} / \mathrm{mL}$ cytochalasin $\mathrm{B}(\mathrm{CB})$, and then the reconstructed embryos were cultured in $\mathrm{PZM}-3$ medium at $39^{\circ} \mathrm{C}$ and $5 \% \mathrm{CO}_{2}$ in humidified air.

\section{Embryo transfer}

Transgenic cloned embryos were cultured in vitro for 0.5-1.5 days. Then, 80-110 embryos were loaded into a straw and were surgically introduced into the oviducts of naturally cycling recipient pigs on day 2 of estrus. Pregnancy in the recipient pigs was checked by ultrasonography on day 30 after embryo transfer.

\section{Detection of transgenic Bama mini-pigs by PCR}

Genomic DNA samples were isolated from the ear tissues of cloned pigs and surrogates using the TIANamp Genomic DNA extraction Kit (TIANGEN, Beijing, China) according to the 
manufacturer instructions. For all samples, amplification of the targeted hGFAP-DsRed gene was performed using the forward primer $5^{\prime}$-CTTCGCCTGGGACATCCT-3' and reverse primer 5'-GGTGTAGTCCTCGTTGTGGG-3'. Thirty cycles of PCR amplification were performed: denaturation at $94^{\circ} \mathrm{C}$ for $30 \mathrm{~s}$; annealing at $55^{\circ} \mathrm{C}$ for $30 \mathrm{~s}$; and extension at $72^{\circ} \mathrm{C}$ for $45 \mathrm{~s}$.

\section{Western blotting}

Protein extraction was performed as previously described (Ahn et al., 2010; Jeong et al., 2013). Negative transgenic porcine muscle, transgenic porcine heart, testicle, kidney, brain, muscle, lung, and liver tissue were washed in PBS, quickly frozen in liquid nitrogen, and then powdered. The powder was transferred to lysis bufferThe lysate was centrifuged for $50 \mathrm{~min}$ at 12,000 rpm. Lysate was separated by SDS-polyacrylamide gel electrophoresis and the proteins transferred to a nitrocellulose membrane. The membrane was blocked overnight at $4^{\circ} \mathrm{C}$ and then washed 3 times in TBST. Mouse monoclonal antibody-RFP (DsRed1:1500, CoWin Biotech, China) and mouse anti$\beta$-actin $(1: 1,000$, CoWin Biotech) were added for $2 \mathrm{~h}$ at room temperature. The membrane was washed and then incubated with secondary antibodies (1:3000) for $1 \mathrm{~h}$. The membrane was tested using Super ECL Plus Western Blotting following the manufacturer instructions.

\section{Statistical analysis}

Data were analyzed after arcsine transformation. Differences between means were analyzed by one-way ANOVA followed by Fisher's LSD test for percentage data of cell cycle stages, apoptosis percentages, and embryonic developmental stages. Differences were considered significant at $\mathrm{P}<0.05$.

\section{RESULTS}

\section{Effects of cell-cycle synchronization protocols on the cell-cycle stage}

The majority of cells were at the G0/G1 stage after synchronization with contact inhibition, serum starvation, or roscovitine. The proportions of cells at G0/G1 did not differ significantly between the contact inhibition and roscovitine treatments (92.11 vs $89.59 \%$ ); however, both were significantly higher than in the serum starvation group $(80.82 \%, \mathrm{P}<0.05$; Table 2 , Figure 1). The proportion of cells at $\mathrm{S}$ phase in the serum starvation group was significantly higher than in the contact inhibition and roscovitine treatment groups (14.99 vs $2.54 \%$ and $6.34 \%$ respectively; $P<0.05)$. The three treatment groups did not differ for the proportion of cells at $G 2 / M(P>0.05$; Table 2).

\begin{tabular}{|c|c|c|c|}
\hline \multirow[t]{2}{*}{ Treatment } & \multicolumn{3}{|c|}{$\%$ Cells at different cell cycle stages (mean \pm SEM) } \\
\hline & G0/G1 & S & G2/M \\
\hline Serum starvation & $80.82 \pm 0.51^{\mathrm{b}}$ & $14.99 \pm 0.82^{\mathrm{a}}$ & $4.19 \pm 0.57^{\mathrm{a}}$ \\
\hline Contact inhibition & $92.11 \pm 0.99^{\mathrm{a}}$ & $2.54 \pm 1.05^{c}$ & $5.35 \pm 1.19^{\mathrm{a}}$ \\
\hline Roscovitine & $89.59 \pm 1.24^{\mathrm{a}}$ & $6.34 \pm 0.62^{b}$ & $4.07 \pm 1.32^{\mathrm{a}}$ \\
\hline
\end{tabular}

a,b,c Values with different superscripts in same columns are significantly different $(P<0.05)$. 

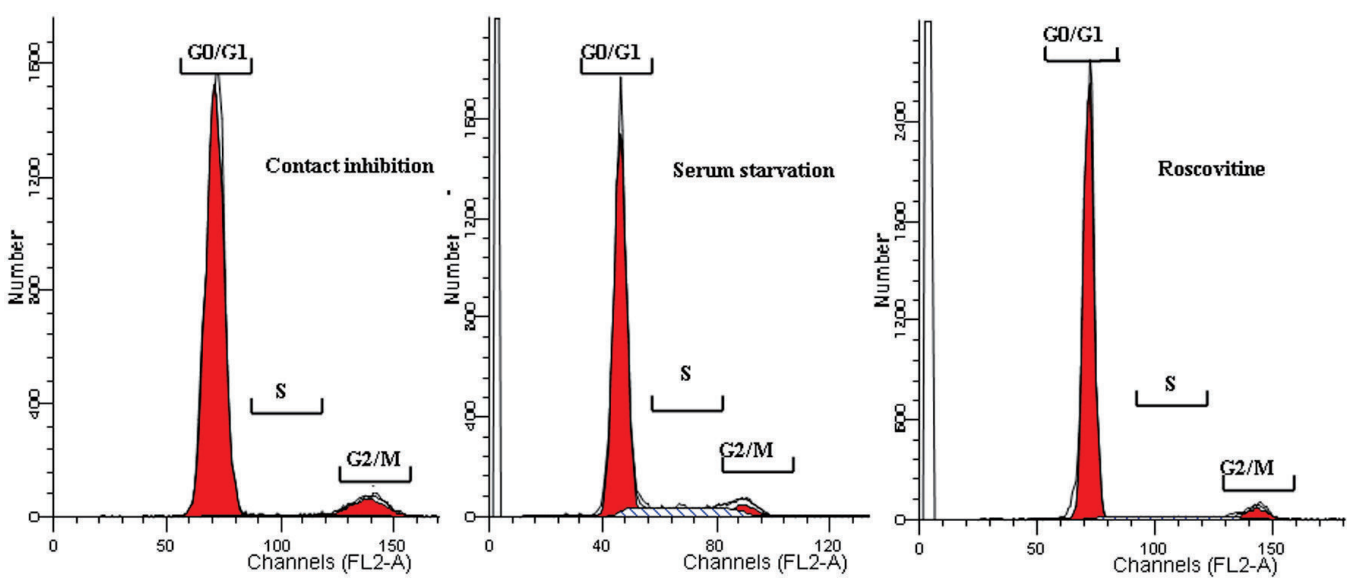

Figure 1. Flow cytometric analysis of cell-cycle in transgenic kidney fibroblasts cultured under different conditions. The single-parameter DNA histogram allows discrimination of cell populations in G0/G1, S, and G2/M phases of the cell cycle.

\section{Apoptosis rates in the three treatment groups}

A significantly higher rate of apoptosis occurred in the serum starvation group than in the contact inhibition or roscovitine treatment groups $(14.13 \pm 3.48 \%$ vs $6.71 \pm 0.29 \%$ and 2.46 $\pm 0.20 \%$, respectively; $P<0.05$; Figure 2 ). There were no differences in the rates of apoptosis between the contact inhibition and roscovitine treatments $(P>0.05)$.

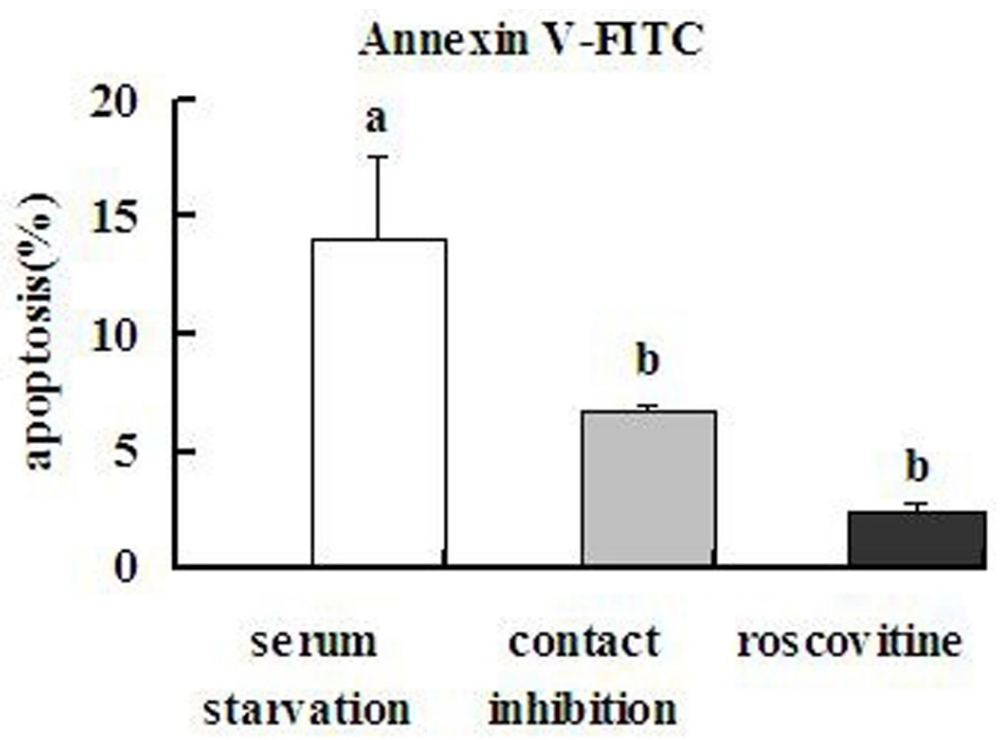

Figure 2. Effect of cell-cycle synchronization protocols on apoptosis in transfected kidney fibroblast cells from a newborn Bama mini-pig. Apoptosis in each treatment group was detected using an Annexin V-FITC Apoptosis Detection Kit. 


\section{Expression of $B A X$ and $B C L-2$ genes}

The level of expression of $B A X$ was significantly higher in the serum starvation group than in the roscovitine and contact inhibition groups $(12.80 \pm 1.36$ vs $1.0 \pm 1.02$ and $1.64 \pm 1.04$, respectively; $P<0.05$, Figure 3$)$, whereas expression of $B C L-2$ was significantly lower in the serum starvation group than in the contact inhibition and roscovitine groups ( $1.0 \pm 1.48$ vs $4.85 \pm 1.05$ and $6.08 \pm 1.01$, respectively; $\mathrm{P}<0.05$, Figure 4).

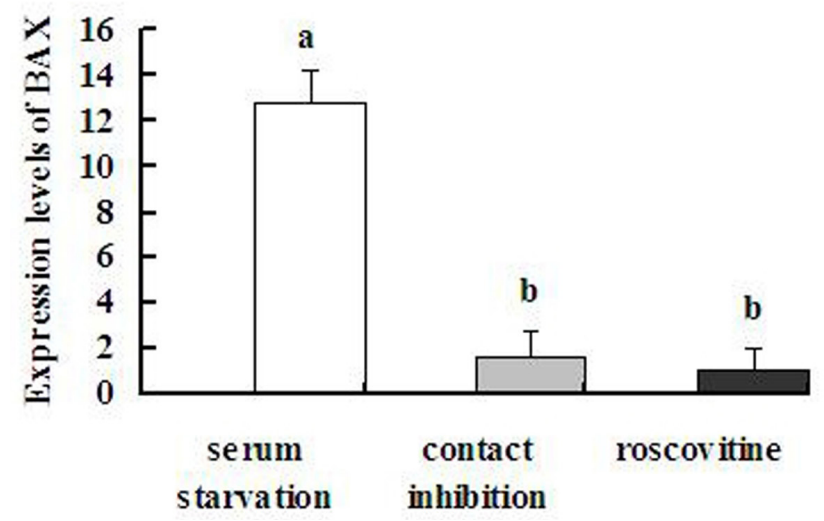

Figure 3. Relative expression level of the pro-apoptotic BAX gene in transgenic porcine fibroblasts cultured under serum starvation, contact inhibition, and roscovitine treatment conditions.

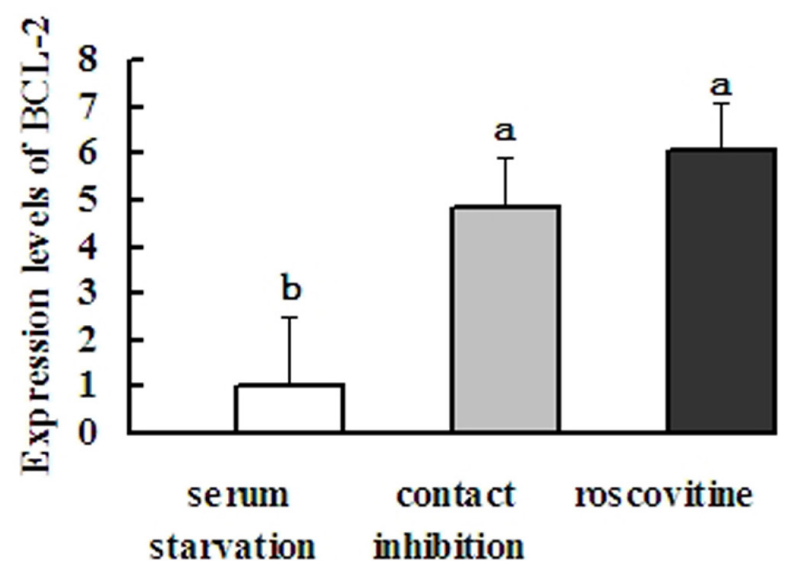

Figure 4. Relative level of expression of the anti-apoptotic $B C L-2$ gene in transgenic porcine fibroblasts cultured under serum starvation, contact inhibition, and roscovitine treatment conditions.

\section{In vitro development of cloned embryos}

Using the cells from different cell-cycle synchronization protocols as donor cells for SCNT, the cleavage rate of cloned embryos in the roscovitine-treated group was significantly higher than in the serum starvation group $(80.69 \pm 1.0 \%$ vs $74.41 \pm 1.5 \% ; P<0.05)$, but not significantly 
different from the contact inhibition group $(78.59 \pm 1.3 \%$; $P>0.05)$. The rate of blastocyst formation in the serum starvation group was significantly lower than in the roscovitine and contact inhibition groups $(14.19 \pm 1.2 \%$ vs $21.31 \pm 0.8 \%$ and $20.32 \pm 0.9 \%$, respectively; $P<0.05$; Table 3 ).

Table 3. Comparison of development rates of SCNT embryos produced using Bama mini-pig transgenic kidney fibroblast cells derived from different cell cycle synchronization protocols.

a,b,c Values with different superscripts in same columns are significantly different $(P<0.05)$.

\section{Production of hGFAP-DsRed transgenic piglets}

A total of 1070 cloned transgenic embryos from the contact inhibition, serum starvation, and roscovitine treatment groups were transferred surgically to 11 recipient sows. Only one pregnancy went to full term (Table 4); three piglets were produced, one was healthy, one died after birth, and one was a difficult birth possibly due to an over-weight body and was stillborn (Figure $5 A$ ). The presence of hGFAP-DsRed in the piglets was confirmed by PCR (Figure 5B). Expression of the hGFAP-DsRed protein in several organs, including kidney, heart, brain, testicle, muscle, lung, and liver, was detected by western blotting (Figure 5C).

Table 4. In vivo development of transgenic cloned embryos derived from the contact inhibition, serum starvation, and roscovitine treatment groups.

\begin{tabular}{lcccc}
\hline Treatment group & No. of transferred cloned embryos & No. of recipients & No. of pregnancies & Piglets \\
\hline Serum starvation & 408 & 4 & 0 & 0 \\
Contact inhibition & 310 & 4 & 1 & 0 \\
Roscovitine & 352 & 3 & 1 & 1 healthy, 1 died during birth, \\
& & & & 1 died after birth \\
\hline
\end{tabular}
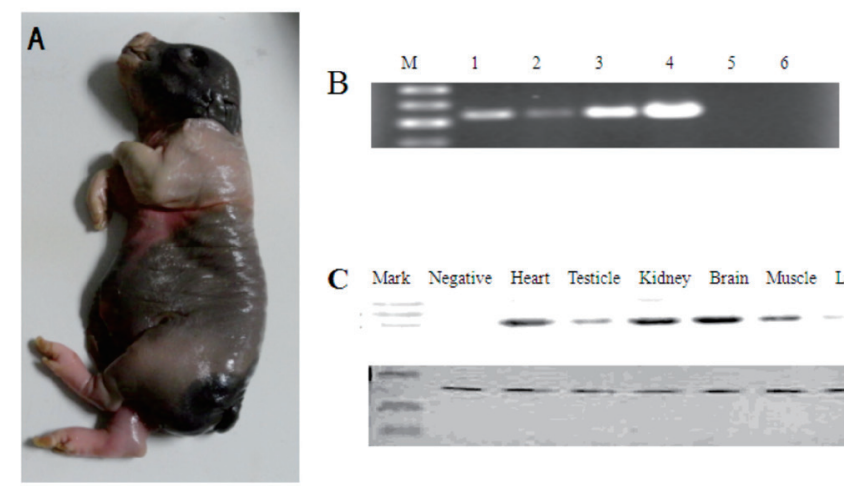

C Mark Negative Heart Testicle Kidney Brain Muscle Lung Liver

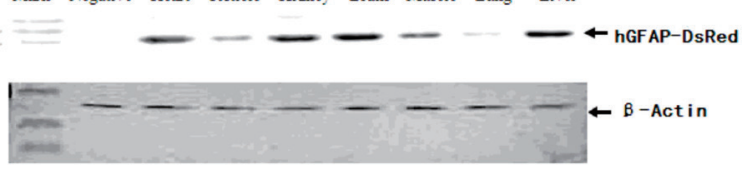

Figure 5. Analysis of hGFAP-DsRed transgenic piglets. A. hGFAP-DsRed transgenic cloned pig derived from roscovitine treatment group. B. Detection of the hGFAP-DsRed gene of the cloned piglet. Lane $M=$ size marker, lane $1=$ muscle; lane 2 = kidney; lane 3 = brain; lane 4 = dilution of plasmid for positive control; lane $5=$ recipient; lane $6=$ non-transgenic pig cells for negative control. C. Western blot analysis of hGFAP-DsRed transgene expression in several organs (heart, testicle, kidney, brain, muscle, lung, and liver) of the transgenic piglet. 


\section{DISCUSSION}

Previous studies have reported that the cell cycle stage of donor cells is an important factor influencing the developmental ability of nuclear transfer embryos (Campbell et al., 1996; Prather et al., 1999). Normal ploidy and integrity is maintained in SCNT cloned embryos when the cell cycle stage of donor cells and recipient oocyte cytoplasm is coordinated. It has also been claimed that it is necessary to use G0 stage cells as donors for SCNT in order to achieve complete reprogramming, although there are reports that cloned animals can be obtained using G1 stage cells for SCNT (Cibelli et al., 1998). Several protocols can be used to arrest cells at G0/G1 stages for use in SCNT. Contact inhibition and serum starvation are the most commonly used methods (Wilmut et al., 2007), but chemicals such as roscovitine and cycloheximide have also been employed (Sun et al., 2008).

Serum starvation can induce apoptosis in porcine granulosa cells and increase expression of the p53 protein (Peng et al., 1998). Although Kues et al. (2000) reported that short periods of serum starvation increased the proportion of porcine fetal fibroblasts at G0/G1 to approximately $80 \%$; prolonged culture led to reduced cell survival and increased DNA fragmentation. However, most of this research was carried out on non-transgenic cells; in the present study, we evaluated the ability of contact inhibition, serum starvation, and roscovitine to synchronize Bama mini-pig kidney fibroblasts transfected with hGFAP-DsRed. Our flow cytometry analysis indicated that $>80 \%$ of the cells were at the G0/G1 stage. Additionally, the rate of apoptosis in the serum starvation treatment group was significantly lower than for contact inhibition and the roscovitine treated groups.

Our analyses here showed higher proportions of G0/G1 cells in the contact inhibition $(92.11 \%)$ and roscovitine treatment groups (89.59\%) compared to the serum starvation group (80.82\%). In contrast, Park et al. (2010) reported that cells serum starvation induced a higher rate of G0/G1 cells $(87.5 \%)$ stage compared to roscovitine $(79.9 \%)$ and contact inhibition groups $(76.3 \%)$. Sun et al. (2008) reported that the efficiency of obtaining G0/G1 cells was lower using roscovitine compared to serum-starvation and contact inhibition (89.7 vs $91.1 \%$ and $91.0 \% ; P<0.05)$. The contrasting outcomes in these studies might be the consequence of the treatment methods, species, or cell type.

Khammanit et al. (2008) reported that serum starvation did not increase the rate of apoptotic

cells; by contrast, in the present study, the rate of apoptosis after $48 \mathrm{~h}$ serum starvation was higher than found for contact inhibition or roscovitine treatments. We also examined the relative levels of expression of apoptosis-related genes, $B A X$ and $B C L-2$. Serum starvation significantly increased expression of $B A X$ but decreased expression of $B C L-2$ compared to roscovitine and contact inhibition. Gibbons et al. (2002) reported that roscovitine treatment predictably synchronized the donor cell cycle of bovine somatic cells and improved their capacity for nuclear reprogramming; as a result, calf survival and cloning efficiency were enhanced. Furthermore, Park et al. (2010) reported that roscovitine treatment of porcine donor cells for SCNT could improve the development of cloned embryos and increase the efficiency of production of cloned piglets. In the present study, contact inhibition, serum starvation and roscovitine treated transgenic cells were used as donor nuclear cells for SCNT, and cloned embryos were cultured in vitro. We found that the blastocyst formation rate in the serum starvation group was significantly lower than in the roscovitine and contact inhibition groups. This may be attributed to the induction of apoptosis, which affected the development of cloned embryos. Miranda et al. (2009) showed that blastocyst production and quality after SCNT were reduced using apoptotic cells induced by serum starvation. Park et al. (2004) found that treatment of donor cells with putative apoptosis inhibitors reduced apoptosis after SCNT and improved the development of cloned embryos. 
Here we tested the in vivo developmental competence of transgenic Bama mini-pig cloned embryos derived from contact inhibition, serum starvation and roscovitine treated transgenic kidney fibroblasts. Only one pregnancy successfully achieved full-term; the cells used for SCNT in this case were roscovitine treated.

In conclusion, we showed that transgenic Bama-mini pig kidney fibroblasts could be synchronized at the G0/G1 stage by serum starvation, roscovitine treatment, or contact inhibition. However, serum starvation increased the rate of apoptosis and the level of expression of the apoptosis-promoting gene $B A X$. Overall, the in vitro and in vivo developmental competence of transgenic Bama mini-pig embryos was improved using roscovitine treated donor cells for SCNT. The results of this study will assist the production of transgenic Bama mini-pigs and aid establishment of pig transgenic models for biomedical research.

\section{Conflicts of interest}

The authors declare no conflict of interest.

\section{ACKNOWLEDGMENTS}

Research supported by the National Natural Science Foundation of China (Grant \#31260553) and Guangxi High Education Innovative Research Group and Eminent Scholar Project. We thank Dr. Bernard A. Goodman for his critical suggestions and revisions of the manuscript.

\section{REFERENCES}

Ahn KS, Won JY, Park JK, Sorrell AM, et al. (2010). Production of human CD59-transgenic pigs by embryonic germ cell nuclear transfer. Biochem. Biophys. Res. Commun. 400: 667-672.

Boquest AC, Day BN and Prather RS (1999). Flow cytometric cell cycle analysis of cultured porcine fetal fibroblast cells. Biol. Reprod. 60: 1013-1019.

Bordignon V and Smith LC (2006). Telophase-stage host ooplasts support complete reprogramming of roscovitine-treated somatic cell nuclei in cattle. Cloning Stem Cells 8: 305-317.

Campbell KH, Loi P, Otaegui PJ and Wilmut I (1996). Cell cycle co-ordination in embryo cloning by nuclear transfer. Rev. Reprod. 1: 40-46.

Cho JK, Lee BC, Park JI, Lim JM, et al. (2002). Development of bovine oocytes reconstructed with different donor somatic cells with or without serum starvation. Theriogenology 57: 1819-1828.

Cibelli JB, Stice SL, Golueke PJ, Kane JJ, et al. (1998).Transgenic bovine chimeric offspring produced from somatic cellderived stem-like cells. Nat.Biotechnol. 16: 642-646.

Fujimura T, Takahagi Y, Shigehisa T, Nagashima H, et al. (2008). Production of alpha 1,3-galactosyltransferase gene-deficient pigs by somatic cell nuclear transfer: a novel selection method for gal alpha 1,3-Gal antigen-deficient cells. Mol. Reprod. Dev. 75: 1372-1378.

Gibbons J, Arat S, Rzucidlo J, Miyoshi K, et al. (2002). Enhanced survivability of cloned calves derived from roscovitine-treated adult somatic cells. Biol. Reprod. 66: 895-900.

Gomez MC, Jenkins JA, Giraldo A, Harris RF, et al. (2003). Nuclear transfer of synchronized African wild cat somatic cells into enucleated domestic cat oocytes. Biol. Reprod. 69: 1032-1041.

Hashem MA, Bhandari DP, Kang SK and Lee BC (2007). Cell cycle analysis and interspecies nuclear transfer of in vitro cultured skin fibroblasts of the Siberian tiger (Panthera tigris Altaica). Mol. Reprod. Dev. 74: 403-411.

Jeong YH, Park CH, Jang GH, Jeong YI, et al. (2013). Production of multiple transgenic Yucatan miniature pigs expressing human complement regulatory factors, human CD55, CD59, and H-transferase genes. PLoS One 8: e63241.

Khammanit R, Chantakru S, Kitiyanant $Y$ and Saikhun J (2008). Effect of serum starvation and chemical inhibitors on cell cycle synchronization of canine dermal fibroblasts. Theriogenology 70: 27-34.

Kitagawa M, Higashi H, Takahashi IS, Okabe T, et al. (1994). A cyclin-dependent kinase inhibitor, butyrolactone I, inhibits phosphorylation of RB protein and cell cycle progression. Oncogene 9: 2549-2557. 
Knosalla C, Yazawa K, Behdad A, Bodyak N, et al. (2009). Renal and cardiac endothelial heterogeneity impact acute vascular rejection in pig-to-baboon xenotransplantation. Am. J. Transplant. 9: 1006-1016.

Koo OJ, Hossein MS, Hong SG, Martinez-Conejero JA, et al. (2009a). Cell cycle synchronization of canine ear fibroblasts for somatic cell nuclear transfer. Zygote 17: 37-43.

Koo OJ, Park HJ, Kwon DK, Kang JT, et al. (2009b). Effect of recipient breed on delivery rate of cloned miniature pig. Zygote 17: 203-207.

Kues WA, Anger M, Carnwath J, Paul D, et al. (2000). Cell cycle synchronization of porcine fetal fibroblasts: effects of serum deprivation and reversible cell cycle inhibitors. Biol. Rep. 62: 412-419.

Lai L, Kolber-Simonds D, Park KW, Cheong HT, et al. (2002). Production of alpha-1,3-galactosyltransferase knockout pigs by nuclear transfer cloning. Science 295: 1089-1092.

Lee GS, Kim HS, Hyun SH, Lee SH, et al. (2005). Production of transgenic cloned piglets from genetically transformed fetal fibroblasts selected by green fluorescent protein. Theriogenology 63: 973-991.

Li D, Zhu B, Ding L, Lu W, et al. (2014). Role of the mitochondrial pathway in serum deprivation-induced apoptosis of rat endplate cells. Biochem. Biophys. Res. Commun. 452: 354-360.

Li J, Liu Y, Zhang JW, Wei H, et al. (2006). Characterization of hepatic drug-metabolizing activities of Bama miniature pigs (Sus scrofa domestica): comparison with human enzyme analogs. Comp. Med. 56: 286-290.

Lindenboim L, Diamond R, Rothenberg E and Stein R (1995). Apoptosis induced by serum deprivation of PC12 cells is not preceded by growth arrest and can occur at each phase of the cell cycle. Cancer Res. 55: 1242-1247.

Liu CT, Yu KC and Ju JC (2004). Cell cycle stage analysis of rabbit foetal fibroblasts and cumulus cells. Reprod. Domest. Anim. 39: 385-390.

Liu H, Lv P, Zhu X, Wang X, et al. (2014). In vitro development of porcine transgenic nuclear-transferred embryos derived from newborn Guangxi Bama mini-pig kidney fibroblasts. In Vitro Cell Dev. Biol. Anim. 50: 811-821.

Liu HB, Lv PR, He RG, Yang XG, et al. (2010). Cloned Guangxi Bama minipig (Sus scrofa) and its offspring have normal reproductive performance. Cell. Reprogram. 12: 543-550.

Liu Y, Zeng BH, Shang HT, Cen YY, et al. (2008). Bama miniature pigs (Sus scrofa domestica) as a model for drug evaluation for humans: comparison of in vitro metabolism and in vivo pharmacokinetics of lovastatin. Comp. Med. 58: 580-587.

McElroy SL, Kim JH, Kim S, Jeong YW, et al. (2008). Effects of culture conditions and nuclear transfer protocols on blastocyst formation and mRNA expression in pre-implantation porcine embryos. Theriogenology 69: 416-425.

Mei J, Yin Z, Zhang J, Lui KW, et al. (2010). A mini pig model for visualization of perforator flap by using angiography and MIMICS. Surg. Radiol. Anat. 32: 477-484.

Miranda MS, Bressan FF, Zecchin KG, Vercesi AE, et al. (2009). Serum-starved apoptotic fibroblasts reduce blastocyst production but enable development to term after SCNT in cattle. Cloning Stem Cells 11: 565-573.

Onishi A, Iwamoto M, Akita T, Mikawa S, et al. (2000). Pig cloning by microinjection of fetal fibroblast nuclei. Science 289: 1188-1190.

Park ES, Hwang WS, Jang G, Cho JK, et al. (2004). Incidence of apoptosis in clone embryos and improved development by the treatment of donor somatic cells with putative apoptosis inhibitors. Mol. Reprod. Dev. 68: 65-71.

Park H, Koo O, Kwon D, Kang J, et al. (2010). Effect of roscovitine treated donor cells on development of porcine cloned embryos. Reprod. Domest. Anim. 45: 1082-1088.

Pedrali-Noy G, Spadari S, Miller-Faures A, Miller AO, et al. (1980). Synchronization of HeLa cell cultures by inhibition of DNA polymerase alpha with aphidicolin. Nucleic Acids Res. 8: 377-387.

Peng X, Maruo T, Matsuo H, Takekida S, et al. (1998). Serum deprivation-induced apoptosis in cultured porcine granulosa cells is characterized by increased expression of p53, Fas antigen and Fas ligand and by decreased expression of PCNA. Endocrine J. 45: 247-253.

Polejaeva IA, Chen SH, Vaught TD, Page RL, et al. (2000). Cloned pigs produced by nuclear transfer from adult somatic cells. Nature 407: 86-90.

Prather RS, Boquest AC and Day BN (1999). Cell cycle analysis of cultured porcine mammary cells. Cloning 1: 17-24.

Selokar NL, Saini M, Muzaffer M, Krishnakanth G, et al. (2012). Roscovitine treatment improves synchronization of donor cell cycle in G0/G1 stage and in vitro development of handmade cloned buffalo (Bubalus bubalis) embryos. Cell Reprogram. 14: 146-154.

Sun X, Wang S, Zhang Y, Wang H, et al. (2008). Cell-cycle synchronization of fibroblasts derived from transgenic cloned cattle ear skin: effects of serum starvation, roscovitine and contact inhibition. Zygote 16: 111-116.

Wakayama T, Perry AC, Zuccotti M, Johnson KR, et al. (1998). Full-term development of mice from enucleated oocytes injected with cumulus cell nuclei. Nature 394: 369-374.

Wells DN, Misica PM and Tervit HR (1999). Production of cloned calves following nuclear transfer with cultured adult mural granulosa cells. Biol. Reprod. 60: 996-1005.

Wilmut I, Schnieke AE, McWhir J, Kind AJ, et al. (2007). Viable offspring derived from fetal and adult mammalian cells. Cloning Stem Cells 9: 3-7. 